\title{
The Notion of "Transnationality" in Administrative Law: Taxonomy and Judicial Review
}

\author{
Emilie Chevalier ${ }^{1 \star *}$ and Olivier Dubos ${ }^{2, * *}$ \\ ${ }^{1}$ Associate Professor of Public Law, University of Limoges, Limoges, France and ${ }^{2}$ Professor of Public Law, University of \\ Bordeaux, Bordeaux, France \\ Corresponding author: Emilie Chevalier, Email: emilie.chevalier@unilim.fr
}

(Received 29 March 2021; accepted 11 April 2021)

\begin{abstract}
This Article deals with the issues related to the judicial review of transnational acts which are adopted particularly within the context of the European integration process. The European Union is a privileged playground for the development of administrative acts of this type, primarily because of the existence of various and diverse administrative cooperation mechanisms. Transnational administrative acts are, either because of their adoption process or because of their conditions of enforcement, governed by at least two national legal orders. The question of the availability of judicial review in the context of transnational administrative acts is a complex one, because the presence of one exogeneous element may disrupt the straightforward path toward the right of access to courts—as both the determination of the competent court and the scope of the review carried out by the court seized become uncertain. This Article first draws up a typology of transnational administrative acts. Second, on the basis of this typology, this Article analyzes the solutions developed by the case law of the Court of Justice and assesses them in the light of the principles of territoriality of administrative law and the right to effective judicial protection.
\end{abstract}

Keywords: Transnationality; administrative act; judicial review

\section{A. Introduction}

The right to an effective remedy and the right of access to courts are fundamental rights protected at the European level by both the European Convention of Human Rights and the Charter of Fundamental Rights of the European Union. ${ }^{1}$ The European integration process has led to the creation of various mechanisms of enforcement of EU law, which makes the path towards access to courts complex and uncertain, because they call into question the boundaries between the national and European spheres of jurisdiction. At the beginning of the process of European integration, these boundaries were rather strictly defined. This is because-as a matter of principlethe enforcement of EU law was mainly organized according to the system of indirect administration, which implied that the national administrative authorities were first and foremost

\footnotetext{
${ }^{*}$ Associate Professor of Public Law, University of Limoges.

${ }^{* *}$ Professor of Public Law, University of Bordeaux.

${ }^{1}$ See European Convention on Human Rights, arts. 6, 13 (Nov. 4, 1950); European Union Charter of Fundamental Rights, art. 47, Dec. 14, 2007, 2007 O.J. (C 303) 17.

(C) The Author(s) 2021. Published by Cambridge University Press on behalf of the German Law Journal. This is an Open Access article, distributed under the terms of the Creative Commons Attribution licence (http://creativecommons.org/licenses/by/4.0/), which permits unrestricted re-use, distribution, and reproduction in any medium, provided the original work is properly cited.
} 
competent to enforce EU law. ${ }^{2}$ The system of indirect administration has been noticeably limited by the development of the system of "co-administration," or, "composite administration." This development brought about the much debated need to define the articulation of the respective jurisdictions of the national and European courts on the administrative acts resulting from those procedures. $^{3}$

Another product of European integration which has been analyzed less by scholars, and is less visible in the European Court of Justice (ECJ)'s case law, is that of transnational administrative acts. These are administrative acts which, by reason of the authority that adopted them, the scope of their effects, their addressee(s), and/or their decision-making process, are "in-between" at least two national legal orders. They are thus a sub-category of the acts adopted following co-administration proceedings, because the latter concept entails both vertical and horizontal mechanisms of administrative cooperation. ${ }^{4}$ Alternatively, the scope of transnational administrative acts is limited to horizontal relationships-i.e. those involving exclusively national administrative authorities.

The issue of judicial review of transnational administrative acts or decisions is not peculiar to European Union law. This type of decision also exists outside the EU legal system, insofar as national administrative authorities from at least two different States are involved in the adoption of an administrative act. ${ }^{5}$ Nevertheless, it is equally true that the European Union is a privileged playground for the development of administrative acts of this type, especially because of the existence of various and diverse administrative cooperation mechanisms 6 -including regulatory structures of purely horizontal cooperation. ${ }^{7}$

The question of the availability of judicial review in the context of transnational administrative acts is a complex one, for at least two reasons. ${ }^{8}$ First, the transnational dimension of an administrative act brings about "contact" between two national legal orders which are at the same level, and between which there is - in the majority of cases_-no relationship of primacy which has been

\footnotetext{
${ }^{2}$ Claudio Franchini, Les Notions d'Administration Indirecte et de Coadministration, in Traite DE DroIT AdminisTratiF Europeen 335, 335-56 (Jean-Bernard Auby \& Jacqueline Dutheil de la Rochère eds., 2014); Bernard Dubey, Administration Indirecte et Fédéralisme d'Exécution en Europe, in 1/2 CAHIERS DE DROIT EUROPEEN 87 (2009); L'EXECUTION DU DROIT DE L'Union Entre Mecanismes Communautaires et Droits Nationaux (Jacqueline Dutheil de la Rochère ed., 1999).

${ }^{3}$ Mariolina Eliantonio, Judicial Review in an Integrated Administration: The Case of Composite Procedures, 7 REV. EUR. Admin. L. 65 (2014); Herwig C.H. Hofmann, Decisionmaking in EU Administrative Law - The Problem of Composite Procedures, 61 Admin. L. Rev. 199 (2009).

${ }^{4}$ Legal Challenges in EU Administrative Law: Towards an InTegrated Administration (Herwig C.H. Hofmann \& Alexander Türk eds., 2009); Jarle Trondal \& Michael W. Bauer, Conceptualizing the European Multilevel Administrative Order: Capturing Variation in the European Administrative System, 9 EUR. PoL. SCI. ReV. 73 (2017); Matthias Ruffert, European Composite Administration: The Transnational Administrative Act, in THE EUROPEAN COMPOSITE Administration 277-306 (Oswald Jansen \& Bettina Schöndorf-Haubold eds., 2011); Eberhard SchmidtAßmann, Le Modèle de l'AAdministration Composée” et le Rôle du Droit Administratif Européen, in RevUE FrancAISE DE DroIT Administratif 1246 (2006).

${ }^{5}$ Angelos Gerontas, Deterritorialization in Administrative Law: Exploring Transnational Administrative Decisions, 19 Colum. J. Eur. L. 423 (2013).

${ }^{6}$ See Luca De Lucia, Administrative Pluralism, Horizontal Cooperation and Transnational Administrative Acts, 5 REV. EUR. Admin. L. 17 (2012); Felipe Brito Bastos, An Administrative Crack in the EU's Rule of Law: Composite Decision-Making and Nonjusticiable National Law, 16 Eur. Const. L. Rev. 63 (2020).

${ }^{7}$ See Giacinto Della Cananea, Transnational Public Law in Europe: Beyond the Lex Alius Loci, in Transnational Law: Rethinking European LaW and Legal Thinking 321-45 (Miguel P. Maduro, Kaarlo Tuori \& Suvi Sankari eds., 2014). See also Felipe Brito Bastos \& Deirdre Curtin, Interoperable Information Sharing and the Five Novel Frontiers of EU Governance: A Special Issue, 26 EUR. PUB. L. 59 (2020) (the issue of information sharing is an important part of transnational activities at EU level).

${ }^{8}$ See Trondal \& Bauer, supra note 4, at 73; Tobias Bach \& Eva Ruffing, The Transformative Effects of Transnational Administrative Coordination in the European Multi-Level System, in THE PALGRAVE HandBoOK OF PUBliC Administration and Management In Europe 747-63 (Edoardo Ongaro \& Sandra van Thiel eds., 2018).
} 
designed to solve the conflicts of laws or the conflict of jurisdictions. ${ }^{9}$ Additionally, according to the basic principle of territoriality of administrative law, ${ }^{10}$ national administrative courts are only competent to review the legality of acts and actions adopted by the authorities of their legal order. However, in cases of transnational administrative acts, the presence of one exogeneous element may disrupt the straightforward path toward the right of access to the courts, as both the determination of the competent court and the scope of the review carried out by the court seized become uncertain. Transnational administrative acts may thus question the orthodox limitations for administrative courts to review a foreign administrative act.

This Article argues that the transnational dimension of an administrative act affects the classical approach towards its review, because the fundamental principles of administrative law may have trouble accommodating this peculiar regulatory mechanism. Nonetheless, in the context of European integration, these fundamental principles governing jurisdiction must be reconciled with the requirements arising from European Union law. Specifically, European principles-such as the right to effective judicial protection or the principle of non-discrimination-require an adaptation or an even greater flexibility of the classical boundaries of judicial review of administrative action.

This Article, after analyzing the complexity of the concept of transnational administrative acts, considering its links with those of extraterritoriality and transnationality (Section B) and drawing up a typology of transnational administrative acts (Section C), will consider the applicable principles for determining the competent court (Section D). Based on the established typology of transnational administrative acts, this Article will eventually analyze the possibilities of judicial control over transnational administrative acts (Section E).

\section{B. From Extraterritoriality to Transnationality}

Public administration is no longer a State function that is exercised solely within the national legal order to which it belongs. It acts in connection with the international legal order and also with foreign legal orders. Transnational administrative law aims to address the latter aspect. Understood in this connotation, transnationality has the same meaning as internationality as understood in private international law_-given the presence of a foreign element in a legal relationship — and therefore differs from internationality as understood in public international law. ${ }^{11}$

If we focus on administrative transnationality as manifested in unilateral administrative acts, the concept of extraterritoriality ought to be added to the analysis. Unlike a contract, a unilateral administrative act is the product of only one legal person and is therefore necessarily, as a matter of principle, linked to the legal system to which its author belongs. Nevertheless, its enforcement may not be located solely in this legal system. This phenomenon can be linked to that of extraterritoriality, which has been the subject of numerous meticulous investigations by public international law scholars. ${ }^{12}$

Brigitte Stern considers that "there is extraterritoriality in the application of a norm if all or part of its process of application takes place outside the territory of the State that issued it." 13 She further specifies that the application of a norm is an operation with different dimensions: "[T]hus,

\footnotetext{
${ }^{9}$ Luca De Lucia, Conflict and Cooperation Within European Administration (Between Philia and Eris), 5 REv. Eur. AdmIN. L. 43 (2012).

${ }^{10}$ Daniel Mockle, Le Débat Sur les Principes et les Fondements du Droit Administratif Global, 1 Les CAHIERS DE DroIT 3 (2012).

${ }^{11}$ Henri Batiffol \& Paul Lagarde, Droit International Prive (1970).

${ }^{12}$ See Harold G. Maier, Extraterritorial Jurisdiction at a Crossroads: An Intersection Between Public and Private International Law, 76 AM. J. INT'L L. 280 (1982); Brigitte Stern, Une Tentative d'Èlucidation du Concept d'Application Extraterritoriale, Revue Quebecoise de Droit InTernationale 49 (1986). See also Raymond J.W. Ritterhof \& Phillipp L. Ullmer, Extraterritoriality: Selective Bibliography, HAGUE ACAD. INT'L L. (Sept. 6, 2019), https://www.peacepalacelibrary.nl/wpcontent/uploads/2019/08/Update-3-Centre-2019-Extraterritoriality-SelectiveBibliography-General.pdf.

${ }^{13}$ See Stern, supra note 12.
} 
elements of extraterritoriality are found when a norm is implemented by an authority outside the territory, or when elements outside the territory are taken into account in the implementation of a norm, or when the application of the norm involves legal effects outside the territory." ${ }^{14}$ In those cases, the jurisdiction of a State extends beyond its territory. ${ }^{15}$ This notion of extraterritoriality may be applied to unilateral administrative acts-as one category of norms in a broad sense-and also to all unilateral legal measures enacted by the State organs of a given legal system.

Public international law distinguishes extraterritoriality according to whether a unilateral action of the State is at stake, or whether the action takes place within the framework of an international treaty or an international organization, including the European Union. ${ }^{16}$ In the first hypothesis, extraterritoriality often encounters a number of obstacles, both legal-in particular its conformity with the rules of public international law-and practical, the difficulties in giving concrete form to an extraterritorial claim. In the second hypothesis, extraterritoriality takes a cooperative shape-it is governed by the treaty establishing it, or by the law of the international organization in which it is enshrined. In the European Union, where the free movement of both natural and legal persons is ensured, cooperation between the administrative authorities of the Member States is necessary to deal with different transnational situations.

Finally, following Prosper Weil, two sides of extraterritoriality ought to be distinguished. ${ }^{17}$ In the first, the State, author of the norm, intends to apply the norm outside its territory - this is what the author refers to as "normative jurisdiction." 18 The norm is conferred by its own legal order a spatial scope of application that goes beyond its territory. ${ }^{19}$ In the second, the State applies a foreign norm within its own territory and thus confers an extraterritorial effect on that foreign norm. ${ }^{20}$ This is a case of so-called "recognitive jurisdiction." ${ }^{21}$ In the case of administrative co-operation, as the eco-system in which EU-generated transnational administrative acts move, this distinction should be viewed in context, because it is by virtue of this specific legal framework that an act of a State A may produce effects in State B, or require the authorities of State B to apply the acts of State A. Nonetheless, this distinction has the merit of highlighting the fact that both authorities of the State from which the act emanates, and also foreign authorities, are often involved in the framework of transnational administrative acts. It also demonstrates that, frequently, a transnational administrative act is part of a chain of acts adopted by authorities of a distinct legal order. Thus, an administrative act from State A allows the enactment of another administrative act from State B, which in turn allows the enactment of another administrative act in State A or even in State C.

In the next section, this Article will explore how the notion of extraterritoriality, elaborated by Stern, and the typology proposed by Weil, can be used to draw up a typology of transnational administrative acts, which are to be regarded as being "in-between" at least two national legal orders.

\footnotetext{
${ }^{14} I d$.

${ }^{15}$ According to the jurisprudence of the PCIJ, enforcement jurisdiction is limited to the territory of the State. See The Case of S.S. Lotus (Fr. v. Turk.), 1927 P.C.I.J. Series A - No. 10 (Sept. 7).

${ }^{16}$ It should be noted that the Strasbourg Court has produced influential jurisprudence regarding the extraterritorial jurisdiction of the States. In particular, in situations where a State exercises "effective control" over an area outside its territory, the Strasbourg Court has accepted the extraterritorial application of the ECHR. See, e.g., Loizidou v. Turkey, 318 Eur. Ct. H.R. 2235 (1998), http://hudoc.echr.coe.int/eng?i=001-58201; Al-Skeini \& Others v. The United Kingdom, App. No. 55721/07 (July 7, 2011), http://hudoc.echr.coe.int/eng?i=001-105606.

${ }^{17}$ Prosper Weil, International Law Limitation on State Jurisdiction, in EXTRATERRITORIAL APPLICATION OF LAWS AND Responses Thereto, 34 (Cecil J. Olmstead ed., 1984).

${ }^{18} I d$.

${ }^{19} \mathrm{Id}$.

${ }^{20} I d$.

${ }^{21} I d$.
} 


\section{Typology of Transnational Administrative Acts}

In order to create a typology of transnational administrative acts, it is possible to use a distinction made by Brigitte Stern. ${ }^{22}$ This allows one to distinguish between the notions of transnational imputation and transnational effect. ${ }^{23}$ An administrative act can be considered of transnational imputation when, for its adoption, it takes into account facts or legal situations existing outside the territory of the authority that enacts it. The foreign element is, in such a case, the basis of the act. An administrative act may instead be considered to have transnational effects if it has consequences outside the territory in which it was enacted. The foreign element is thus the consequence of the enforcement of the act. These two hypotheses are not necessarily mutually exclusive, as administrative acts may be both of transnational imputation and with transnational effects.

\section{Acts of Transnational Imputation}

The act of transnational imputation may itself take different forms. It may be an act that necessitates, for its application, from a factual element located abroad. The simplest and best-known example is the worldwide taxation principle. The income of a person residing in a State is taxed in that State regardless of whether the income is produced there or abroad. The act of taxation is therefore enacted on the ground of national as well as foreign facts. ${ }^{24}$

The existence of such a factual element located abroad may imply, within the framework of a process of administrative cooperation, that a transnational procedure presides over the enactment of the administrative act of transnational imputation. This is indeed the case, for example, in tax matters, where States exchange information in order to determine a taxpayer's overall taxable income. $^{25}$

Another example is that of Directive 2011/92/EU on the assessment of the effects of certain public and private projects on the environment. ${ }^{26}$ This instrument provides that, where a project has an impact on the territory of another Member State other than the Member State where the project is to be authorized, "a public inquiry" may also take place in that State. The authorization given to such a project will thus be issued on the basis of factual elements located in the territory of another State.

An act of transnational imputation may also be an act of recognition. In such situations, a State will issue an administrative act in order to give effect to another administrative act issued in another State. By giving effect to a foreign act in its legal order, the act of recognition constitutes an act of transnational imputation, because its raison d'être lies in an element located in a foreign legal order. The best-known example is that of driving licenses. An international treaty adopted within the framework of the United Nations organizes this mutual recognition of driving licenses. ${ }^{27}$ States may also decide unilaterally to recognize a foreign driving license.

\footnotetext{
${ }^{22}$ See Stern, supra note 12.

${ }^{23} I d$.

${ }^{24}$ In France, for example, see Art. 4A of the CODE GÉNÉRAL DES IMPÔTS (GENERAL TAX CODE) ("Persons who have their tax domicile in France are liable to income tax on their entire income. Those whose tax domicile is outside France are liable to this tax solely because of their income from French sources.") (Authors' own translation).

${ }^{25}$ See Convention on Mutual Administrative Assistance in Tax Matters, Amended by the 2010 Protocol, art. 4 (June 1, 2011) [hereinafter Convention on Mutual Administrative Assistance in Tax Matters] https://www.oecd.org/ctp/exchange-of-taxinformation/ENG-Amended-Convention.pdf; see also Council Directive 2011/16/EU of 15 February 2011 on Administrative Cooperation in the Field of Taxation and Repealing Directive 77/799/EEC, 2011 O.J. (L 64) 1.

${ }^{26}$ Directive 2011/92/EU of the European Parliament and of the Council of 13 December 2011 on the Assessment of the Effects of Certain Public and Private Projects on the Environment, 2012 O.J. (L 26) 1.

${ }^{27}$ United Nations Convention on Road Traffic, art. 41, Nov. 8, 1968.
} 
In France, this possibility exists for nationals of countries outside the European Union who become residents in France. ${ }^{28}$

In a relatively analogous manner, an act of transnational imputation can also be an act of execution. In this case, the State will not merely recognize the legal effects of the foreign act, but will also give it concrete execution. For example, Article 1(1) of Council Directive 2001/40/EC allows a Member State to enforce an expulsion decision taken by an authority of another Member State against a third country national. ${ }^{29}$ The execution measure is an act of transnational imputation, because it gives effect to a measure adopted by a foreign legal order. It should be stressed that transnational acts of execution are often by-products of underlying mechanisms of administrative cooperation. In such situations, the transnational administrative act of State A is conditioned by an administrative act of State B, which will pose a certain number of difficulties at the stage of judicial review. ${ }^{30}$

\section{Acts with Transnational Effects}

To begin, it is necessary to mention that, outside any cooperative process, a State may intend to give extraterritorial effect to an administrative act it enacts. The best-known example is that of the Amato Kennedy's laws, which allowed the President of the United States to impose sanctions on foreign companies that invested in Libya or Iran. ${ }^{31}$

In the vast majority of cases, however, the transnational effect of an administrative act is set up by an international treaty or by European Union law. In those cases, States may provide that some of their administrative acts will produce effects beyond the limits of their territory. These can be factual or legal effects. An act produces de facto transnational effects when it has an impact or is likely to have an impact on the territory of another State. One example is an environmental authorization in a border area or an expulsion order returning a foreigner to his State of origin.

Instead, an act produces a legal effect mainly when it has an impact on the legal situation of a person, property, or a good located in the territory of a State other than the State of the authority that enacted it. This effect can manifest itself in different ways.

First, this effect may be automatic and not require the intervention of the receiving State. For instance, Article 19(1) of Directive 2001/18/EC provides that:

[W]ithout prejudice to requirements under other Community legislation, only if a written consent has been given for the placing on the market of a GMO as or in a product may that product be used without further notification throughout the Community in so far as the

\footnotetext{
${ }^{28}$ The French Road Traffic Code provides that:

Any valid national driving license issued by a State that is neither a member of the European Community nor a party to the Agreement on the European Economic Area may be recognized in France until the expiration of one year after the acquisition of the normal residence of its holder. During this period, it may be exchanged for a French license, without the holder being required to take the examinations provided for in the first paragraph of Article R 221-3. The conditions for this recognition and exchange are defined by order of the Minister in charge of Transport, after consulting the Minister of Justice, the Minister of the Interior and the Minister for Foreign Affairs. At the end of this period, this license is no longer recognized and its holder loses all rights to drive a vehicle for which a driving license is required.

Code de la Route [C. Route] [Road Traffic Code] art. R 222-3 (Fr.) (authors' own translation).

${ }^{29}$ Directive 2001/40/EC of the Council of 28 May 2001 on the Mutual Recognition of Decisions on the Expulsion of Third Country Nationals, art. 1, 2001 O.J. (L 149) 34 ("Without prejudice to the obligations arising from Article 23 and to the application of Article 96 of the Convention implementing the Schengen Agreement of 14 June 1985, signed at Schengen on 19 June 1990, hereinafter referred to as the 'Schengen Convention,' the purpose of this Directive is to make possible the recognition of an expulsion decision issued by a competent authority in one Member State, hereinafter referred to as the 'issuing Member State,' against a third country national present within the territory of another Member State, hereinafter referred to as the 'enforcing Member State.").

${ }^{30}$ See infra Sections D \& E.

${ }^{31}$ See 50 U.S.C. $35 \$ 1701$ (1996). See also 22 U.S.C. $\$ 6021$ (1996).
} 
specific conditions of use and the environments and/or geographical areas stipulated in these conditions are strictly adhered to. ${ }^{32}$

The transnational effect of a decision placing a GMO on the market is therefore automatic. ${ }^{33}$

In a second scenario, the act will produce an effect beyond the territory of the State of the authority which enacted it, only if it is followed by an act of recognition by the receiving State. For example, in order to ensure freedom of establishment for lawyers, Article 10 of Directive 98/5/EC requires a decision by the competent authority of that State to permit assimilation to the profession of lawyer in the host Member State. ${ }^{34}$ The transnational effect in this scenario is therefore subject to an act of recognition. ${ }^{35}$

In a third scenario, the concerned act is an act which does not only produce legal effects, but also requires concretization. Therefore, it may imply an act of execution. EU law sometimes provides for the possibility for the State which is the author of the act to enforce it extraterritorially. According to Article 35(9) of Directive 2014/65/EU

[E]ach Member State shall provide that, where an investment firm authorised in another Member State has established a branch within its territory, the competent authority of the home Member State of the investment firm, in the exercise of its responsibilities and after informing the competent authority of the host Member State, may carry out on-site inspections in that branch. ${ }^{36}$

Therefore, in this case, there is a system of transnational execution. The act has transnational effects because foreign administrative authorities are obliged to execute it in their legal order. This solution is all the more remarkable in that it derogates from the principle of prohibition of extraterritorial enforcement laid down by the Permanent Court of International Justice in the Lotus case. ${ }^{37}$

\section{The Links Between Transnational Imputation and Transnational Effects}

As discussed above, if an act is of transnational imputation, it is that way only because it concerns a situation that is not solely located in the territory of the State charged with enacting the act. There is instead a factual or legal element of the act that is extraterritorial. An act of transnational imputation can also produce transnational effects, or be part of a chain of acts, in which acts of transnational imputation and acts of transnational effect are interlinked. These links between transnational imputation and transnational effects are found in situations of administrative cooperation where extraterritoriality is not unilateral, but organized through an international treaty or European Union law. Indeed, administrative cooperation is a means for States to ensure the effectiveness of their public policies in cases where they intend to regulate transnational situations.

In a first scenario, the same act can be both of transnational imputation and have transnational effects. When a national act is likely to produce a factual effect abroad, the administrative cooperation that is established appears as a response to that factual effect. For example, the aforementioned Directive 2011/92/EU—on the assessment of the effects of certain public and private projects on the environment-also allows the organization of a public inquiry in the territory of a

\footnotetext{
${ }^{32}$ Directive 2001/18/EC of the European Parliament and of the Council of 12 March 2001 on the Deliberate Release Into the Environment of Genetically Modified Organisms and Repealing Council Directive 90/220, 2001 O.J. (L 106) 1.

${ }^{33}$ See, e.g., Rui Lanceiro \& Mariolina Eliantonio, The Genetically Modified Organisms' Regime: A Playground For Multi-Level Administration And A Nightmare For Effective Judicial Protection, in this issue.

${ }^{34}$ Directive 98/5/EC of the European Parliament and of the Council of 16 February 1998 to Facilitate Practice of the Profession of Lawyer on a Permanent Basis in a Member State Other than that in Which the Qualification was Obtained, 1998 O.J. (L 077) 36.

${ }^{35}$ See Luis Arroyo-Jimenez, Effective Judicial Protection and Mutual Recognition in the European Administrative Space, in this issue.

${ }^{36}$ Directive 2014/65/EU of the European Parliament and of the Council of 15 May 2014 on Markets in Financial Instruments and Amending Directive 2002/92/EC and Directive 2011/61/EU, 2014 O.J. (L 173) 349.

${ }^{37}$ See Lotus, supra note 15.
} 
border State, where a decision is likely to have a de facto effect on the territory of this State. ${ }^{38}$ Here the transnational imputation of the act-for example, the fact that the final act of the decisionmaking process, an authorization, must take the results of the consultation organized in a foreign State into account-is the consequence of the de facto transnational effect of the decision.

There are also acts that produce transnational legal effects, while at the same time being of transnational imputation. Administrative cooperation in tax matters provides an example of such a situation. When the authorities of State A request information from the authorities of State B, the request for information is an act of transnational imputation, because it is based on facts located in State B-in other words, the fact that is at the origin of the request for information - but it is also an act with transnational effects, as the authorities of State B will have to respond to the requests of State A. ${ }^{39}$ Insofar as administrative cooperation does not only concern the exchange of tax information, but also the recovery of tax claims, the act of taxation can be regarded as an act of transnational imputation. This is not only because it concerns foreign income, but also because it produces transnational effects, as it will have to be executed by foreign authorities. ${ }^{40}$

This link between transnational imputation and transnational effect exists in many acts adopted by the national authorities of the Member States of the European Union in the implementation of EU law. For example, under Regulation 1/2003, national authorities may be given the power to impose administrative sanctions against foreign companies. ${ }^{41}$ Such sanctions constitute an act of transnational imputation insofar as it concerns the conduct of a person located within the territory of another Member State. To the extent that these sanctions fall within the scope of Council Framework Decision 2005/214/JHA on the application of the principle of mutual recognition to financial penalties, ${ }^{42}$ they also produce a transnational effect.

In a second scenario, there is a chain of administrative acts in which an act of transnational effect and an act of transnational imputation follow one another. This is the case in mutual recognition mechanisms. Where the act with transnational effects of State A does not produce an automatic effect abroad, it requires an act of recognition in State B, which therefore constitutes an act of transnational imputation. ${ }^{43}$

It is possible to summarize the typologies of transnational administrative acts as shown in the table below.

Table 1: Typology of transnational administrative acts

\begin{tabular}{|c|c|c|}
\hline & Without transnational effects & With transnational effects \\
\hline $\begin{array}{l}\text { Without transnational } \\
\text { imputation }\end{array}$ & "Purely" national administrative act & $\begin{array}{l}\text { a) Factual effects } \\
\text { - expulsion order returning a foreigner } \\
\text { to his State of origin: Article } 6 \text { of } \\
\text { Directive } 2008 / 115 / E C \text { - common stan- } \\
\text { dards and procedures for returning } \\
\text { illegally staying non-EU nationals } \\
\text { b) Legal effects } \\
\text { - Automatic effect: Article } 19(1) \text { of } \\
\text { Directive } 2001 / 18 / \text { EC of the European } \\
\text { Parliament and of the Council of } 12 \\
\text { March } 2001 \text { on the deliberate release }\end{array}$ \\
\hline
\end{tabular}

(Continued)

\footnotetext{
${ }^{38}$ See supra Section C(1).

${ }^{39}$ See Convention on Mutual Administrative Assistance in Tax Matters, supra note 25, at arts. 5-32.

${ }^{40} I d$. art. 11.

${ }^{41}$ Council Regulation 1/2003 of 16 December 2002 on the Implementation of the Rules on Competition Laid Down in Articles 81 and 82 of the Treaty, 2002 O.J. (L 1) 1.

${ }^{42}$ Council Directive 2005/214/JHA, 2009 O.J. (L 76) 16.

${ }^{43}$ See Directive 98/5/EC, supra, note 34 , at art. 10.
} 
Table 1: (Continued.)

\begin{tabular}{|c|c|c|}
\hline & Without transnational effects & With transnational effects \\
\hline & & $\begin{array}{l}\text { into the environment of genetically } \\
\text { modified organisms and repealing } \\
\text { Council Directive } 90 / 220 / E E C \text {; } \\
\text { - Effect subject to recognition: Article } \\
10 \text { of Directive } 98 / 5 / E C \text { of the } \\
\text { European Parliament and of the } \\
\text { Council of } 16 \text { February } 1998 \text { to facili- } \\
\text { tate practice of the profession of law- } \\
\text { yer on a permanent basis in a Member } \\
\text { State other than that in which the } \\
\text { qualification was obtained; } \\
\text { - Execution: Article } 35(9) \text { of Directive } \\
\text { 2014/65/EU on markets in financial } \\
\text { instruments. }\end{array}$ \\
\hline $\begin{array}{l}\text { With transnational } \\
\text { imputation }\end{array}$ & $\begin{array}{l}\text { a) Act with a foreign factual } \\
\text { element } \\
\text { - Tax deed for income received } \\
\text { abroad when there is no } \\
\text { international } \\
\text { cooperation } \\
\text { b) Act of recognition or execu- } \\
\text { tion of a foreign act } \\
\text { - Recognition: Article } 41 \text { of the } \\
\text { United Nation Convention on road } \\
\text { Traffic, Vienna, } 8 \text { November } 1968 \text {; } \\
\text { - Execution: Article } 1(1) \text { of the } \\
\text { Council Directive } 2001 / 40 / E C \text { on } \\
\text { the mutual recognition of deci- } \\
\text { sions on the expulsion of third } \\
\text { country nationals. }\end{array}$ & $\begin{array}{l}\text { a) Factual effects } \\
\text { - Article } 7 \text { of Directive } 2011 / 92 / E U \text { on the } \\
\text { assessment of the effects of certain public } \\
\text { and private projects on the environment. } \\
\text { b) Legal effects } \\
\text { - Articles } 11 \text { and following of the } \\
\text { Convention on Mutual Administrative } \\
\text { Assistance in Tax Matters, Amended by the } \\
2010 \text { Protocol, entered into force June } 1 \text { st } \\
2011 \text {, developed jointly by the OECD and } \\
\text { the Council of Europe. } \\
\text { - Council Regulation (EC) No } 1 / 2003 \text { of } 16 \\
\text { December } 2002 \text { on the implementation of } \\
\text { the rules on competition laid down in } \\
\text { Articles } 81 \text { and } 82 \text { of the Treaty combined } \\
\text { with Council Framework Decision } 2005 / \\
214 / J H A \text { on the application of the principle } \\
\text { of mutual recognition to financial penalties }\end{array}$ \\
\hline
\end{tabular}

\section{The Relevant Principles to Determine the Competent Court to Review a Transnational Administrative Act}

The determination of the competent court to review a transnational administrative act may not be straightforward. Due to the act's transnational dimension, as well as its administrative nature, it is worth recalling that the question of the competent court cannot be solved according to the classical principles of private international law. ${ }^{44}$ Indeed, the resolution of this problem presents certain specificities, given the link between the exercise of public power-and thus of State sovereignty - and the adoption of an administrative act. It is worth noting in this respect that the Brussels I Regulation, which provides for conflict rules applicable for the determination of the competent court is not applicable to "administrative matters or to the liability of the State for acts and omissions in the exercise of State authority (acta iure imperii)." ${ }^{35}$ The rationale for this exclusion is rooted in the idea that the assessment of the legality of an administrative act is an exercise which is closely linked to the exercise of State sovereignty. Classically, judicial review

\footnotetext{
${ }^{44}$ Michel Bauer, Le Droit Public Etranger Devant le Juge du For (1977); Charalampos Pampoukis, L'Acte Public Etranger en Droit International Prive (1993).

${ }^{45}$ Regulation $1215 / 2012$ of the European Parliament and of the Council of 12 December 2012 on Jurisdiction and the Recognition and Enforcement of Judgments in Civil and Commercial Matters, art. 1, 2012 O.J. (L 351 ) 1.
} 
is a mechanism which aims at safeguarding the respect of the rule of law, ${ }^{46}$ and thereby the validity of rules in a given legal order. It is up to the national court of the particular national legal order to ensure that valid norms are enforceable in that State's order. The relevant principles applicable to determine the competent court to review a transnational administrative act are thus those resulting from classical public law rules, as supplemented - in the context of the EU-from European Union law.

First, the question of the court having jurisdiction to review an administrative act is solved by referring to the principle of territoriality of administrative law, according to which the administrative situations of State A are intended to be governed solely by the law of that State. This principle, which itself derives from the notion of national sovereignty, makes it impossible to subject the exercise of public authority to a foreign State. The same logic underlies jurisdictional immunities under public international law. ${ }^{47}$ For this reason, a court has no power to review the legality and thereby potentially affect the validity of an act produced by a foreign State. Consequently, as a matter of principle, an action against a foreign administrative act-such as an act adopted by a foreign public authority - is not admissible before a court belonging to another legal order.

Second, in the context of European law, any solutions developed in order to review transnational administrative acts, adopted to enforce EU law, must comply with the principle of effective judicial protection and the right to an effective remedy enshrined in Article 47 of the Charter of Fundamental Rights, as well as the European Court of Justice's case law. ${ }^{48}$ According to the court's case law, "it is for the Member States to ensure judicial protection of an individual's rights under Community law," ${ }^{\prime 9}$ and to provide for adequate remedies to challenge national acts falling within the scope of EU law. ${ }^{50}$ Hence, as far as a transnational administrative act enforces EU law, it is necessary to guarantee effective access to a court, as well as access to a court which may be fully competent to review this act.

The transnational dimension of the administrative action may create obstacles to the enforcement of such principles due to the involvement of multiple State legal orders and national courts. In particular, two kinds of difficulties may be identified in this respect.

First, there may be situations in which several courts may be regarded as having jurisdiction over an administrative act. In these situations, the question arises as to whether only one court is competent to hear the case, or if the applicant has a choice. The opposite situation may also occur-when no court considers itself competent to review a transnational administrative act-for example, if the action is considered as inadmissible in a given legal order.

Second, with respect to transnational administrative acts, the exercise of the right to an effective remedy is still generally conditioned upon overcoming a number of legal and practical obstacles. ${ }^{51}$ Obstacles which may relate to the conditions for standing and the capacity to act in a given legal system. In this respect, it is essential that persons of foreign nationality-including a foreign public authority-be allowed to bring an admissible action before a court. Concerning this question, the French Conseil d'Etat has, for example, accepted that a foreign State may refer to it a decision refusing extradition. ${ }^{52}$ In addition, practical obstacles be ignored, such as language issues, questions of access to the law, and to knowledge of legal remedies. This includes the identification of the competent court in a foreign system. If the transnational decision falls within the scope of EU

\footnotetext{
${ }^{46}$ Thomas Poole, Legitimacy, Rights and Judicial Review, 25 OXFord J. LEGAL STUD. 697 (2005); Doreen Lustig \& Joseph H.H. Weiler, Judicial Review in the Contemporary World-Retrospective and Prospective, 16 ICON 315 (2018).

${ }^{47}$ Joe Verhoeven, Le Droit InTERnAtional DES Immunities: CONTESTATION OU CONSOlidation? (2004).

${ }^{48}$ Paolo Mazzotti \& Mariolina Eliantonio, Transnational Judicial Review in Horizontal Composite Procedures: Berlioz, Donnellan, and the Constitutional Law of the Union, 5 EUR. PAPERS 1 (2020).

${ }^{49}$ ECJ, Case C-432/05, Unibet (London) Ltd. \& Unibet (International) Ltd. v. Justitiekanslern, ECLI:EU:C:2007:163, (Mar. 13, 2007), para. 38, http://curia.europa.eu/juris/liste.jsf?num=C-432/05.

${ }^{50}$ Felipe Brito Bastos, Derivative Illegality in European Composite Administrative Procedures, 55 COMMON MKT. L. REV. 101 (2018).

${ }^{51}$ See De Lucia, supra note 6.

${ }^{52}$ CE Ass., Oct. 15, 1993, 142578, Rec. Lebon (Fr.).
} 
law, the EU principle of non-discrimination ${ }^{53}$ is also relevant when the question of access to court is at issue. On this ground, discrimination on the grounds of nationality among the applicants is forbidden. ${ }^{54}$

When transnational administrative decisions are issued in the context of the implementation of EU law, secondary EU legislation might provide an answer to the question of the competent court to review a transnational administrative act. For example, under Regulation No. 2016/679 (GDPR), Article 78(3) states that, "[P] roceedings against a supervisory authority shall be brought before the courts of the Member State where the supervisory authority is established." 55 The regulation sticks to a classical vision of territoriality, according to which the administrative acts of a public authority can only be challenged before a court belonging to the same legal order. This regime has the advantage of avoiding any competition among national courts, as it provides for the designation of only one national court. Nevertheless, such a legal regime, solving in advance the potential conflicts of jurisdiction in cases of transnational administrative acts, exists only in limited cases. Most often, such jurisdictional conflicts need to be solved on the basis of national law.

As a matter of principle, and because there is only limited EU harmonization in the field of procedural administrative law, the procedural conditions for the enforcement of EU law at the national level ${ }^{56}$ on the basis of the principle of institutional and procedural autonomy, ${ }^{57}$ are defined by each national system. As there is a risk that this system might bring about discriminatory treatment between applicants in different Member States-depending on the national court before which an action is brought - national procedural autonomy has been limited by the principles of effectiveness and equivalence. According to the former principle, the procedural conditions at a domestic level may not render excessively difficult or impossible in practice the exercise of rights derived from EU law. The principle of equivalence instead requires that procedural conditions applicable to claims based on EU law may not be less favorable than those applicable to purely national claims. ${ }^{58}$

These principles also naturally govern the question of judicial review of transnational administrative acts when these acts are taken in implementation of EU law. More precisely, in the context of EU law, the principle of territoriality of administrative law may be subject to limitations or at least, adaptations, in order to ensure compliance with these principles. ${ }^{59}$ The next section will examine the extent to which European law, as interpreted by the European Court of Justice, provides solutions and ways of balancing the territoriality principle with the right to an effective remedy.

\section{The Extent of Review of Transnational Administrative Decisions}

Following the typology of transnational administrative acts provided above, the question of the judicial review of these acts shall be distinguished according to whether the transnational decision is without or with transnational imputation.

\footnotetext{
${ }^{53}$ Gareth Davies, Nationality Discrimination in the European Internal Market (2003); Gillian More, The Principle of Equal Treatment: From Market Unifier to Fundamental Right?, in The Evolution OF E.U. LAW 517-52 (Paul Craig \& Grainne de Burca eds., 1999).

${ }^{54}$ See generally Treaty on the Functioning of the European Union, art. 18, Oct. 26, 2012, 2012 O.J. (C 326) 47. See, e.g., Case C-43/95, Data Delecta Aktiebolag \& Ronny Forsberg v. MSL Dynamics Ltd., ECLI:EU:C:1996:357 (Sept. 26, 1996) http://curia. europa.eu/juris/liste.jsf?language $=$ en $\&$ num $=$ C-43/95; Case C-20/92, Anthony Hubbard (Testamentvollstrecker) v. Peter Hamburger, (July 1, 1993) http://curia.europa.eu/juris/showPdf.jsf;jsessionid=928120015F79339CFAFB578DD97CBD53? text $=\&$ docid $=98302 \&$ pageIndex $=0 \&$ doclang $=\mathrm{EN} \&$ mode $=1 \mathrm{st} \& \operatorname{dir}=\& o c \mathrm{c}=$ first $\&$ part $=1 \& \mathrm{cid}=681761$.

${ }^{55}$ Commission Regulation 2016/679 of the European Parliament and of the Council of 27 April 2016 on the Protection of Natural Persons with Regard to the Processing of Personal Data and on the Free Movement of Such Data, and Repealing Directive 95/46 (General Data Protection Regulation), 2016 O.J. (L 119), 1.

${ }^{56}$ Mariolina Eliantonio \& Elise Muir, The Incidental Proceduralisation of EU law, 8 REALAW (2015).

${ }^{57}$ Diana-Urania Galetta, Procedural Autonomy of EU Member S tates: Paradise Lost? (2010).

${ }^{58}$ EJC, Case 33/76, Rewe-Zentralfinanz v. Finanzamt Köln-Mitte, ECLI:EU:C:1976:188 (1976), http://curia.europa.eu/juris/ liste.jsf?language $=$ en $\&$ jur $=\mathrm{C}, \mathrm{T}, \mathrm{F} \&$ num $=\mathrm{C}-347 / 04 \& \mathrm{td}=\mathrm{ALL}$

${ }^{59}$ Giacinto della Cananea, From the Recognition of Foreign Acts to Trans-national Administrative Procedure, in Recognition of Foreign Administrative Acts 219-42 (Jaime Rodriguez-Arana Muñoz ed., 2016).
} 


\section{Judicial Review of Administrative Acts Without Transnational Imputation and with Transnational Effects}

As mentioned above, a transnational administrative act without transnational imputation may either be a "pure" national administrative act, or an act with transnational effects. Leaving aside the typology of "pure" administrative acts, where no questions of transnationality arise, this section will examine the possible gaps of judicial protection arising in cases of acts which have transnational effects, but lack transnational imputation.

The starting point for the question of judicial review and the competent court in such cases is the territoriality principle. The basis of this principle is that judicial review of administrative acts can only be carried out by the court of the legal system from which the act emanates. ${ }^{60}$ In the case of administrative acts with transnational effects, this principle will, however, entail the disconnection between the legal system in which the act has been adopted and those in which the act will effect.

This type of administrative act can be challenged in several ways. First, it may be challenged through the usual avenues foreseen for non-transnational administrative acts-the Court of the system from which the act originated-because, from the perspective of the legal system of origin, the administrative act is not transnational. In this case, there is no gap of judicial protection, and the principle of territoriality does not constitute an obstacle to the exercise of the right to an effective remedy, but rather a safeguard for it. From the perspective of the individual claimant, however, while the transnational nature of this administrative act does not constitute a radical obstacle to the exercise of the right of access to the court, it can make it more complex-as it will entail the initiation of a claim in a foreign legal system.

Second, another option for access to the courts would be to bring a claim against the transnational administrative act in the receiving state. This would be done if and when the authorities of this state adopt an act based on the effects of the transnational act, such as an act of recognition or of execution. In these cases, the transnational administrative act is part of a decision-making process of adoption of an act by the receiving state. The latter is thus, from the perspective of the receiving state-an administrative act with transnational imputation. The question of the gaps of judicial review in the context of acts of transnational imputation is the subject matter of the next section.

\section{Judicial Review of Transnational Administrative Acts of Transnational Imputation and with Transnational Effects}

The difference with the hypothesis discussed above-administrative acts with transnational effects, but without transnational imputation-lies in the fact that when an act is of transnational imputation, the national decision which may be challenged directly before the competent national court is based on factual or legal elements, or even a decision adopted in another legal order by a foreign public authority. From this perspective, the decision may be regarded as a composite decision-a decision adopted following different stages which are split among different national legal orders - that depend on different acts and decisions by national authorities belonging to various legal systems. ${ }^{61}$

Additionally, in such cases, in accordance with the territoriality principle, the court is, in principle, not allowed to directly review a foreign act. A strict understanding of this principle has the effect of granting jurisdictional immunity to this act in the receiving legal system.

\footnotetext{
${ }^{60}$ Maxence Chambon, Le Conflit de Lois Dans l'Espace et le Droit Administratif (2015).

${ }^{61}$ Edoardo Chiti, The Administrative Implementation of European Law: A Taxonomy and its Implications, in LEGAL Challenges in European Administrative law: The Move Towards an Integrated Administration, 9-33 (Herwig C.H. Hofmann \& Alexander Türk eds., 2009); Paul Craig, Shared Administrations and Networks: Global and EU Perspectives, in Values in Global Administrative Law 81-116 (Gordon Anthony, Jean-Bernard Auby, John Morison \& Tom Zwart eds., 2011).
} 
One possibility to fill this gap of judicial protection might be to allow an indirect review of these foreign acts. The system of indirect control of legality allows the claimant to challenge the act that constitutes the legal basis for a decision which is the subject of a direct challenge. In such cases, the powers of the court are generally more limited than in a direct action. The act indirectly challenged may typically only be "set aside" inter partes and not annulled erga omnes. ${ }^{62}$ If applied to the context of acts of transnational imputation, one might envisage a solution on the basis of which the court of the legal order adopting the final act may not be in a position to question the validity of a foreign administrative act, but only its effects in its domestic legal order. In the specific context of EU law, the presence of European Union rules applicable to the case might be seen as the trigger to open up the possibility for the court of a Member State to assess the legality of an act in a different Member State. The principle of loyal cooperation, on the basis of which all national courts are responsible for the correct enforcement of EU law, might allow-or possibly even require-these courts to review foreign acts for compliance with the applicable EU framework.

In a limited number of rulings, the European Court of Justice was asked to provide for solutions concerning the possibility of indirectly challenging foreign administrative acts adopted in the course of a horizontal composite procedure. In those cases, the European court was called to weigh two fundamental principles of EU law against each other. On the one hand, the immunity of the act from judicial review in the receiving state can be regarded as being required by the principle of mutual recognition. This principle says that a decision adopted in one Member State shall produce an effect, without any additional control in any other Member States. ${ }^{63}$ On the other hand, the principle of effective judicial protection calls such a solution into doubt, because it would limit the possibility for judicial review by forcing the claimant to go before the court of the legal system of origin of the act. This would potentially create difficulties accessing the court, especially if the act is of a preparatory nature and therefore unlikely to be reviewed by that court.

The first of the relevant rulings adopted in this respect is Berlioz, a Grand Chamber decision. ${ }^{64}$ In this case, the French tax authorities had sent the Luxembourg tax authorities a request for information concerning Berlioz under Directive 2011/16. ${ }^{65}$ Following that request, the Director of the Direct Taxation Administration of Luxembourg took a decision in which he stated that the French tax authorities were verifying the tax situation of Cofima, a subsidiary company of Berlioz, and needed information in order to be able to decide on the application of withholding taxes on the dividends paid by Cofima to Berlioz. ${ }^{66}$ In that decision, the administrative authority, on the basis of Luxembourg domestic law, ordered Berlioz to provide him with certain information. ${ }^{67}$ The company complied with this requirement, with the exception of some information which it did not consider relevant within the meaning of Directive 2011/16 for the control carried out by the French tax authorities. ${ }^{68}$ The Luxembourg administrative authority imposed on Berlioz, on the basis of national law, an administrative fine of 250,000 Euros because of its refusal to provide the required information. ${ }^{69}$ The decision was challenged by the company, which asked the

\footnotetext{
${ }^{62}$ While this is not a rule common to all legal systems, it is a solution adopted by many Member States. See Emilie Chevalier, Chapter 7 "Remedies", in CASEs, Materials and TeXt on Judicial Review of Administrative Action $555-690$ (Chris Backes \& Mariolina Eliantonio eds., 2019).

${ }^{63}$ Kalypso Nicolaïdis, Trusting the Poles? Constructing Europe Through Mutual Recognition, 14(5) J. EUR. PUB. POL'Y 682 (2007); Kalypso Nicolaïdis \& Gregory Shaffer, Transnational Mutual Recognition Regimes: Governance Without Global Government, 68 L. \& Contemp. Probs. 263 (2005).

${ }^{64}$ ECJ, Case C-682/15, Berlioz Investment Fund SA v. Directeur de l'Administration des Contributions Directes, ECLI:EU: C:2017:373 (May 16, 2017), http://curia.europa.eu/juris/liste.jsf?num=C-682/15.

${ }^{65}$ Council Directive 2011/16 of 15 February 2011 on Administrative Cooperation in the Field of Taxation and Repealing Directive 77/799, 2011 O.J. (L 64) 1.

${ }^{66}$ Berlioz, Case C-682/15 at para. 22

${ }^{67}$ Id. at para. 23

${ }^{68} I d$. at para. 24

${ }^{69} \mathrm{Id}$. at para. 25
} 
Luxembourg court to review the merits of the decision-as the decision was based on the request made by the French national authorities. ${ }^{70}$ The central question posed to the Court of Justice concerned the scope of the control that could, and even should, be carried out by the Luxembourg court-especially with respect to whether the lack of relevance of the requested information could be contested, which would call into question the French request with regard to EU law and the requirements of Directive 2011/16. ${ }^{71}$ For the purposes of this Article, it should be highlighted that the Luxembourg decision is an act of transnational imputation, because it has its raison d'être in the French authorities' request.

In the ruling, one can identify two opposing lines of reasoning to determine the extent of jurisdiction of the Luxembourg court to review the French decision. The first is based on the obligation of cooperation which exists - on the basis of the Directive, between the national authorities - and also because of the principle of loyal cooperation, enshrined in Article 4 TEU, which applies to both European and national authorities. ${ }^{72}$ The principle requires that European and national authorities, as well as national authorities amongst themselves, cooperate in good faith in adopting and implementing Union standards. ${ }^{73}$ Moreover, the principle of mutual trust, a central principle of the internal market, also applies in interactions between administrations, and may imply that an administrative act of an authority of a Member State is not called into question if it is intended to apply and produce effects in another Member State. ${ }^{74}$ From this perspective, the control carried out by a foreign national court may undermine the effectiveness of this cooperation and even be considered as an infringement of the obligation of loyal cooperation.

The second view is based on the right to effective judicial protection, and on the effectiveness of European Union law, especially that of Directive $2011 / 16 .^{75}$ In this respect, the recognition of the jurisdiction of the Luxembourg court to review the decision of request for information adopted by French administrative authorities may be regarded as functional to ensure the correct enforcement of EU law. It is this second conception that ended up prevailing in the Court of Justice's approach. The Court recalled that, on the basis of Article 20(2) of Directive 2011/16, the requested authority, in this case the Luxembourg authorities, is obliged to check the regularity of the request for information and must verify "that the information sought is not devoid of any foreseeable relevance having regard to the identity of the taxpayer concerned and that of any third party asked to pro-

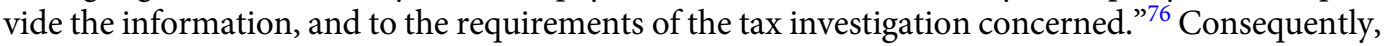
the Luxembourg court was considered empowered to review whether the Luxembourg authorities complied with this obligation imposed by secondary European Union law. ${ }^{77}$ Moreover, in order to guarantee the right to an effective judicial remedy, deriving from Article 47 of the Charter of Fundamental Rights, the national court "must be in a position in which it may carry out the review of the legality of the request for information." 78 Hence, the Luxembourg court was considered competent to indirectly review the administrative act adopted by the French authorities, because it constituted the basis of the Luxembourg decision which was the direct subject matter of the claim. Additionally, it was found competent as, the review of legality was made in relation to an EU norm, and not in relation to national law. Thus, such judicial control does not lead to making the validity of

\footnotetext{
${ }^{70} I d$. at para. 26

${ }^{71} I d$. at para. 31

${ }^{72}$ Marcus Klamert, The Principle of Loyalty in E.U. LaW (2014).

${ }^{73}$ Eleftheria Neframi, Principe de coopération loyale et principe d'attribution dans le cadre de la mise en oeuvre du droit de l'Union, in 1 CAHIERS DE DROIT EUROPEEN 221 (2015).

${ }^{74}$ Recognition of Foreign Administrative Acts (Jaime Rodriguez-Arana Munoz ed., 2016); Alberto Alemanno, Le principe de la reconnaissance mutuelle au-delà du marché intérieur: phénomène d'exportation normative ou stratégie de "colonialisme" règlementaire?, in 2 REVUE DU DROIT DE L'UNION EUROPEENNE 273 (2006).

${ }^{75} \mathrm{Berlioz}$, Case C-682/15 at para. 44 .

${ }^{76} I d$. at para. 82 .

${ }^{77} I d$. at para. 59

${ }^{78} I d$. at para. 84 .
} 
an administrative act conditional on compliance with foreign standards. Such a solution, which aims to guarantee the right to an effective remedy, also contributes to reinforcing the effectiveness of EU law -in the case of Directive 2011/16, a fundamental task of national courts under European law. The innovation brought by the Berlioz case is the extension of the obligation to ensure the full effect of EU law, even where the infringement of an EU norm is the act of an administrative authority of another Member State. ${ }^{79}$

In the more recent Donnellan case, ${ }^{80}$ the Court of Justice confirmed that national courts are competent to review not only the substance of foreign administrative acts, but also their compliance with procedural requirements. Such a solution might seem rather self-evident, because substance might be regarded as more sensitive than procedure with regard to the discretion of national competent authorities. In the context of EU law, however, substantive aspects are typically the object of a harmonization process, whereas procedural requirements are left to national law, in accordance with the principle of procedural autonomy. The ECJ ruling is interesting because the European court specifies the conditions under which the principle of territoriality and the principle of mutual trust, on the one hand, and the right to an effective remedy, on the other hand, may be reconciled. The case dealt with the enforcement of Directive 2010/24 concerning mutual assistance for the recovery of claims relating to taxes, duties and other measures, ${ }^{81}$ and especially its Article 14. The applicant, Mr. Eamonn Donnellan, an Irish citizen, challenged before an Irish court the recovery of a claim consisting of a fine imposed on him by a Greek customs authority. ${ }^{82}$ In accordance with the Directive, Greek authorities had asked the Irish competent authorities for assistance in recovering the fine. The Irish authorities considered that they were, on the grounds of the Directive, required to give a positive response to the request for recovery and to proceed with enforcement of that request. ${ }^{83} \mathrm{Mr}$. Donnellan challenged the injunction brought by Irish authorities, claiming that he was deprived of his right to an effective remedy in Greece, because he had not been notified of the fine ${ }^{84}$ In this case, therefore, the point raised was whether the Irish authorities were-in accordance with the principle of mutual recognition-bound to give effect to the request from the Greek authorities, or, conversely if the right to an effective remedy was to prevail, and the Irish authorities were allowed, under EU law, to decline the Greek request. ${ }^{85}$

The Court recalled the importance of the principle of mutual trust, especially in case of enforcement of mutual assistance mechanisms. Even if it stressed the fundamental nature of the right to an effective remedy, the court ruled that:

[I]t does not in any way follow that the acts of the applicant Member State must be capable of being challenged both before the courts of that Member State and before those of the requested Member State. On the contrary, that system of mutual assistance, as it is based, in particular, on the principle of mutual trust, increases legal certainty with regard to the

\footnotetext{
${ }^{79}$ Case C-106/77, Amministrazione delle Finanze dello Stato v. Simmenthal SpA, ECLI:EU:C:1978:49 (Mar. 9, 1997), para. 21, http://curia.europa.eu/juris/fiche.jsf.

${ }^{80}$ Case C-34/17, Eamonn Donnellan v. The Revenue Comm'rs ECLI:EU:C:2018:282, (Apr. 26, 2018) http://curia.europa.eu/ juris/liste.jsf?num=C-34/17. For an extensive discussion of the case, see Mazzotti \& Eliantonio, supra note 48; Leo Neve, The Berlioz-Decision of the CJEU Provides Legal Protection for Concerned Persons in Transnational Setting, but Will it Hold in the International Arena?, 10 Rev. Eur. Admin. L. 95 (2017); Alexandre Maitrot de la Motte, Cour de Justice, gde ch., 16 mai 2017, Berlioz Investment Fund SA c/ Directeur de l'Administration des Contributions Directes, aff. C-682/15, ECLI:EU:C:2017:373, in Jurisprudence DE LA CJUE DeCisions et Commentaires 2018, 450-466 (2019).

${ }^{81}$ Council Directive 2010/24 of 16 March 2010 Concerning Mutual Assistance for the Recovery of Claims Relating to Taxes, Duties and Other Measures, 2010 O.J. (L 84) 1.

${ }^{82}$ Donnellan Case C-34/17 at para. 30

${ }^{83} I d$. at para. 32 .

${ }^{84} I$ d. at para. 33 .

${ }^{85} I d$. at para. 38 .
} 
determination of the Member State in which disputes are settled and thus makes it possible to avoid forum shopping. ${ }^{86}$

Such a statement seems to support the enforcement of the territoriality principle and the unwillingness of the Court of Justice to open the possibility to challenge foreign administrative acts before a national court. Indeed, the Court continued by stating that:

[I]t follows that the action which the person concerned brings in the requested Member State, seeking rejection of the demand for payment addressed to him by the authority of that Member State which is competent for the recovery of the claim made in the applicant Member State, cannot lead to an assessment of the legality of that claim. ${ }^{87}$

The Court admitted, however, that an infringement of the right to an effective remedy in Greece could justify a derogation to the requirement of mutual assistance as provided for by the Directive. ${ }^{88}$ As a consequence, the Irish judge was deemed competent to review the legality of the Greek decision to impose the fine.

Thus, the failure of a Member State to provide an effective judicial remedy definitively justifies, as the Court pointed out, the jurisdiction of the court of another Member State to assess the legality of the foreign act and, on the basis of that assessment, the possibility of calling into question the obligation of mutual assistance. ${ }^{89}$ Therefore, while in this judgment the right to effective remedy prevails, the principle remains that, where possible, it is the court of the legal order of the administrative authority that adopted the act that is first and foremost competent.

Another more recent case should also be mentioned, the ruling Etat Luxembourgeois $v . B,^{90}$ which took place in a similar context to the Berlioz judgment. The Court of Justice clarified the scope of the right of access to an effective remedy against decisions of national authorities to request additional information to authorities of another Member State on the basis of Directive 2011/16. The ruling gave the Court the opportunity to confirm the extent of the scope of judicial review in cases of actions against decisions with transnational imputation. It held, in particular, that:

[T] he court having jurisdiction must review whether the statement of reasons for that decision and for the request on which that decision is based is sufficient to establish that the information in question is not manifestly devoid of any foreseeable relevance, having regard to the identity of the taxpayer concerned, that of the person holding that information, and the requirements of the investigation concerned. ${ }^{91}$

Therefore, national courts remain competent to review the ground of the foreign decision at the origin of the request for information.

It is interesting to note that such a solution, allowing for a national court to review a foreign act on grounds of EU law, was also acknowledged by the French Conseil d'Etat. Its case law offers

\footnotetext{
${ }^{86} I d$. at para. 45 .

${ }^{87} \mathrm{Id}$. at para. 46.

${ }^{88}$ Fatima Chaouche \& Julia Sinnig, Assistance Administrative Internationale, Procédures Luxembourgeoises et Droits Fondamentaux - Quelques Réflexions au Lendemain de l'Arrêt Berlioz, 52 J. TRIBUNAux 101 (2017).

${ }^{89}$ Donnellan Case C-34/17 at para. 40. See Christine Hagueneau-Moizard, Les Bienfaits de la Défiance Mutuelle dans l'Espace de Liberté, de Sécurité et de Justice, in Europe(s), Droit(s) Europeen(s)- Une Passion D'Universitaire, Liber Amirocum en l'Honneur du Professeur Vlad Constantinesco 223-40 (2015); Koen Lenaerts, La Vie Après l'Avis: Exploring the Principle of Mutual (Yet Not Blind) Trust, 54 Common MKT. L. Rev. 805 (2017).

${ }^{90}$ ECJ, Case C-245/19, État Luxembourgeois v. B \& Others, ECLI:EU:C:2020:795 (Oct. 6, 2020) http://curia.europa.eu/juris/ liste.jsf?num $=\mathrm{C}-245 / 19$.

${ }^{91} I d$. at para. 116.
} 
interesting examples, ${ }^{92}$ even if the rulings are not always very clear. In the Forabosco case, ${ }^{93}$ a French administrative court examined the legality of a decision refusing entry into French territory. That decision was based on a SIS alert, according to which the national authorities are bound to refuse entry to their territory to a third-country national who is the subject of such a request. ${ }^{94}$ Nonetheless, in that judgment, the supreme administrative court held that it had jurisdiction to examine the reasons for the Italian decision, in particular whether the applicant constituted a threat to public policy justifying his entry. ${ }^{95}$ It pointed out that:

[I]t is for the administrative court, when hearing submissions against an administrative decision based on an alert issued on a person's alert for the purpose of refusing entry, to rule on the merits of the plea that the alert is unjustified even though it has been issued by a foreign administrative authority. ${ }^{96}$

This solution was confirmed by the Catrina ruling, ${ }^{97}$ which held that the administrative courts are not competent to assess the legality of the decisions taken by the national authorities which may have led to the registration of the applicant in the SIS. Thus, they cannot review the lawfulness of the procedure for adopting the foreign administrative decision refusing access to the territory which was adopted according to national procedure. In concrete terms, what the court reviews is the existence of facts or legal decisions which make it possible to identify the existence of a threat justifying entry in the SIS file. Admittedly, such a position may be regarded as calling into question the principle of mutual trust, which would imply recognizing immunity to foreign decisions. Thus, the Forabosco and Catrina judgements bring forward a distinction in the scope of competence of the national court to review indirectly a foreign administrative decision. If the plea relates to the grounds of the decision, which are then based on secondary EU law, the court has jurisdiction. On the contrary, if the plea concerns the adoption procedure, which is usually not provided for in EU law, the national court has no jurisdiction. Interestingly, this distinction is the same as the one drawn by the Court of Justice in the Berlioz and the Donnellan rulings. What emerges from this distinction is that the scope of the national court's competence to indirectly review a transnational decision is conditioned by the content and scope of secondary EU law.

Finally, in a recent ruling, R.N.N.S. and K.A., ${ }^{98}$ the Court of Justice confirmed the extent of national courts' jurisdiction to assess the legality of acts with transnational imputation. In this case, the decision to refuse a Schengen visa was grounded on an objection raised by another Member State. ${ }^{99}$ The Court concluded that, while a national court is competent to review the legality of the decision to refuse a visa, the same court is not competent to review the substantive legality of the decision of

\footnotetext{
${ }^{92}$ Timothée Paris, La Reconnaissance des Actes Administratifs Étrangers, 2 Rev. INT'L L. CoMP. 631 (2014); JeanBernard Auby, Le juge administratif et les conflits de lois, in 4 Droit AdMINISTRATIF 1 (2001); JEAN Foyer, LE CONSEIL D’ÉTAT ET LE Conflit des lois Melanges Dedies a Dominique Holleaux 103-20 (1990).

${ }^{93}$ CE Ass., June 9, 1999, Forabosco, ECLI:FR:CESSR:1999:190384.19990609

${ }^{94}$ Commission Regulation 1987/2006 of the European Parliament and of the Council of 20 December 2006 on the Establishment, Operation and Use of the Second Generation Schengen Information System (SIS II), 2006 O.J. (L 381 ) 4.

${ }^{95}$ For a confirmation of the power of administrative national authorities to assess to what extent a thirdcountry national may be considered as a threat to public policy, even if the latter has been the subject of an SIS alert, see ECJ, Case C-503/03, Comm'n of the Eur. Cmtys. v. Kingdom of Spain, ECLI:EU:C:2006:74 (Jan. 31, 2006) http://curia.europa.eu/juris/liste.jsf?language=en\&num= C-503/03. It is important to note that this solution is justified by the fact that the third-country national, as a member of the family of a Member State national, should enjoy enhanced protection against expulsion decisions. This is why it is possible to call into question the principle of loyal cooperation by requiring the national authorities to verify the reality of the threat to public order.

${ }^{96}$ CE Ass., Forabosco.

${ }^{97}$ CE Ass., May 23, 2003, Catrina, 237934, ECLI:FR:CESSR:2003:237934.20030523; Marie Gautier, Le Dépassement du Caractère National de la Juridiction Administrative Française: le Contentieux Schengen, in 5 DroIT ADMINISTRATIF 7 (2005)

${ }^{98}$ ECJ, Case C-225/19, R.N.N.S. \& K.A. v. Minister van Buitenlandse Zaken, ECLI:EU:C:2020:951 (Mar. 14, 2019) http:// curia.europa.eu/juris/liste.jsf?language $=$ en $\& \mathrm{td}=\mathrm{ALL} \&$ num $=\mathrm{C}-226 / 19$.

${ }^{99} \mathrm{Id}$. at para. 14
} 
objection, which is the ground for the national decision to refuse a visa. ${ }^{100}$ The court's control is instead limited to verifying "that the procedure of prior consultation of central authorities of other Member States described in Article 22 of the Visa Code has been applied correctly, in particular by checking whether the applicant was correctly identified as the subject of the objection at issue, and that the procedural guarantees, such as the obligation to state reasons referred to in paragraph 46 above, have been respected in the case in question." ${ }^{101}$ The review of the substantive legality of the objection decision falls instead within the jurisdiction of the courts of the State that raised the objection. ${ }^{102}$ Such an option does not affect the right to an effective remedy. The Court notes that a direct appeal may be exercised before the court of the legal system to which the authority which issued the objection belongs, it will allow a full review of the legality of the decision. ${ }^{103}$ As pointed out above, such a solution does not deprive the individual of access to the court, but may make it more complicated to enforce in practice. An added value of the ruling is to strengthen the obligations imposed on the administrative authorities to ensure that the addressee of the decision to refuse a visa is informed of the available means of appeal. ${ }^{104}$

Through its case-law, the Court of Justice has thus contributed to clarify the means of access to judicial review in cases of an act of transnational imputation and with transnational effects. The Berlioz ruling has opened up the possibility for the national court to review this type of act when grounded in European Union law, and has clarified that a national court should be able to review, indirectly, the conformity of a foreign act which serves as a basis for the national decision. Nevertheless, recent rulings confirm the existence of certain limits to the competence of the court in the indirect review of foreign administrative acts. On the one hand, the scope of the court's jurisdiction varies according to the degree of precision of secondary Union law. Thus, the review of compliance with procedural requirements is conditioned by the scope of the relevant European legislation. On the other hand, the review of the grounds, which result from a foreign administrative act, depends on the discretion of the national authorities. As such, in the recent R.N.N.S. and K.A. ruling, the limitation of the scope of the national court's review may be explained by the fact that the national administrative authorities have, under the Schengen Code, a wider discretion when objecting to the adoption of a visa. In contrast, the national administrative authorities had less discretion as seen in the Berlioz judgment, on the basis of Article 5 of Directive 2011/16, where the requested authorities have an obligation to transmit requested information. ${ }^{105}$

\section{E. Conclusion}

While transnational administrative acts are not new, the context of European integration has sketched a new scenario with respect to those regulatory mechanisms, which requires the re-thinking of ways to construct the system of judicial review. The determination of a competent court, as well as the scope of review, cannot be designed according to the classical conflict of laws rules resulting from private international law.

On the one hand, the territoriality principle must be taken into account for the determination of the competent court in case of judicial review of transnational administrative law. On the other

\footnotetext{
${ }^{100} I d$. at para. 52

${ }^{101} I d$. at para. 51.

${ }^{102} I d$. at para. 52 .

${ }^{103} I d$. at para. 56.

${ }^{104} I d$. at para 52 (" $[\mathrm{I}] \mathrm{t}$ is for the competent authorities of the Member State which adopted the final decision refusing a visa to indicate the authority which the applicant may contact in order to ascertain the remedies available to that end in that other Member State.").

${ }^{105}$ Council Directive 2011/16 of 15 February 2011 on Administrative Cooperation in the Field of Taxation and Repealing Directive 77/799, 2011 O.J. (L 64) 1 ("[A]t the request of the requesting authority, the requested authority shall communicate to the requesting authority any information referred to in Article 1(1) that it has in its possession or that it obtains as a result of administrative enquiries.").
} 
hand, the application of this principle ought not to affect the right to an effective remedy protected by both the ECHR and the Charter of Fundamental Rights alike. We claim that the softness of the borders of administrative action requires the softening of those surrounding the system of judicial review. The transnational nature of an administrative act ought not to render it immune from judicial review, if compliance with the requirement of Article 47 of the Charter of Fundamental Rights is to be ensured.

In the case of administrative acts without transnational imputation, but with transnational effects, a direct action for judicial review before the competent court of the legal order which adopted the act could offer an adequate answer. Its concrete enforcement might face obstacles, however, because it may imply for the applicant the need to bring an action before the court of a foreign legal system. With respect to transnational acts with transnational imputation, EU law provides for solutions grounded on a balance between mutual trust and right to an effective remedy. What looks decisive to solve the issue of judicial review is the existence of common rules, in this case of EU origin, which can be used as a benchmark to review the legality of transnational decisions, ${ }^{106}$ and which can open opportunities for the court to review a foreign administrative act.

Clearly, the development of horizontal composite administrative procedures leads to an extension of the responsibility of the national courts for the correct application of EU law at a national level, which must be understood as no longer being limited to the framework of its own legal order. Nevertheless, the solutions developed by the Court of Justice, while trying to ensure the respect of the right to an effective remedy, may create other issues, such as the possibility that several courts might consider themselves as having jurisdiction over an administrative act. While indeed the Court of Justice has accepted that - in the system of integrated administration created by EU law - an administrative court may review a foreign act which constitutes the basis for a domestic act, this solution does not prevent the court of the legal order adopting the act from reviewing its own domestic acts. Such a solution may, at first sight, look rather favorable to the applicant, as it provides for several fora of judicial review. Nonetheless, it also creates a risk of potential contradictions in the assessment of legality of an administrative act. Some scholars have advanced the idea of horizontal preliminary ruling proceedings as a solution able to reconcile the interests of the applicants and the preservation of the competence of national courts and bring more clarity in the division of jurisdiction between different courts. ${ }^{107}$ The ever-closer cooperation between national administrative authorities within the European Union might mean strengthening the channels of cooperation between the judges competent to review their action. The R.N.N.S. et K.A case seems to show that one way to fill possible gaps in judicial review of transnational administrative act will be found in the procedural deepening of the mechanisms of administrative cooperation-with the administrative authorities having to become more involved in the anticipation of subsequent litigation challenges.

\footnotetext{
${ }^{106}$ Marie Gautier, Acte Administratif Transnational et Droit de l'Union Européenne, in Traité De Droit AdminisTratiF Européen 1303-15 (Jean-Bernard Auby \& Jacqueline Dutheil de la Rochère eds., 2014); Juan Jose Pernas García, The EU's Role in the Progress Towards the Recognition and Execution of Foreign Administrative Acts: The Principle of Mutual Recognition and the Transnational Nature of Certain Administrative Acts, in RECOGNITION OF ForeIGN AdMINISTRATIVE ACTs 15-31 (Jaime Rodriguez-Arana Muñoz ed., 2016).

${ }^{107}$ See Hofmann, supra note 3, at 213-14.

Cite this article: Chevalier E, Dubos O (2021). The Notion of "Transnationality" in Administrative Law: Taxonomy and Judicial Review. German Law Journal 22, 325-343. https://doi.org/10.1017/glj.2021.15
} 